\title{
Correspondence
}

Br Heart f 1983; 50: 196

\section{M-mode echocardiographic features of endomyocardial fibrosis}

Sir,

I was much interested to read this paper published in British Heart fournal 1982; 48: 222-8. It contains some highly interesting facts.

It is, however, necessary to make two observations. -Firstly, it deals with nine cases of right ventricular and six cases of biventricular endomyocardial fibrosis, but none of purely left. Secondly, the inherent characteristics of each are not clearly defined and this creates confusion.

From our own experience of 45 cases already published in 1979 and $1981^{1-3}$ we have been able to specify the M-mode echocardiographic features and confirm them by cardiac catheterisation and angiocardiography.

In 37 patients with exclusively or predominantly right sided endomyocardial fibrosis, we found interventricular septum abnormalities similar to those found by George $e t a l$., as well as changes in the dimensions of the outflow tract and abnormalities of the valves. In 10 patients with exclusively or very predominantly left ventricular involvement, we found septal movement to be large and straight with the original $M$ shaped pattern retained in diastole. We also noted interesting subvalvular abnormalities.

We would also emphasise how valuable we in Abid- jan have found echocardiography to be in assessment of these patients after they have been operated upon here. ${ }^{4}$

\author{
E Bertrand, A Ekra, \\ Institut de Cardiologie, \\ BP V 206, Abidjan, \\ Ivory Coast.
}

\section{References}

1 Dienot B, Ekra A, Bertrand E. L'echocardiographie dans 23 cas de fibroses endomyocardiques constrictives droites ou bilatérales. Arch Mal Coeur 1979; 72: 1101-7.

2 Diénot B, Ekra A, Bertrand E. Signes échocardiographiques dans 10 cas de fibrose endomyocardique constrictive gauche isolée ou bilatérale à prédominance gauche. Arch Mal Coeur 1981; 74: 1063-70.

3 Dienot B, Ekra A, Bertrand E. Diagnostic échocardiographique de la fibrose endomyocardique constrictive (a propos de 45 cas). Cardiol Trop 1981; 7: 107-13.

4 Bertrand E, Chauvet J, Odi Assamoi M, et al. Evaluation des resultats du traitement chirurgical de la fibrose endomyocardique. Etude de 31 malades operés et 30 malades non opéres. Bull Acad Natl Med (Paris) 1983; 166: (in press).

\section{Notices}

\section{European Society of Cardiology}

An International Symposium on "Myocardial revascularisation in acute conditions", sponsored by the European Society of Cardiology will take place in Brussels on 3, 4, and 5 November 1983.

For further information write to Mrs R Fonteyne, Avenue du Vossegat 16, B-1180 Bruxelles, Belgium.

\section{British Cardiac Society}

The Autumn Meeting will be held at Wembley on 21 and 22 November 1983, and the closing date for abstracts was 26 July 1983.

The Annual General Meeting for 1984 will take place in Leicester on 11 and 12 April 1984, and the closing date for receipt of abstracts will be 3 January 1984.

The Autumn Meeting in 1984 will be held on 3 and 4 December 1984, and the closing date for receipt of abstracts will be 15 August 1984. 